\title{
Implementasi Metode K-Means Clustering Berdasarkan Aspek Kognitif dan Afektif Siswa SMP pada Game Pembelajaran Mitigasi Bencana Gunung Api
}

\author{
Muhammad Firyal Alfarisi, Fresy Nugroho, Muhammad Faisal
}

\begin{abstract}
Natural disaster many occurs in Indonesia, one of the natural disaster that occurs in Indonesia is the volcano disaster. In handling with volcanic disasters, the students need more knowledge about volcanic disaster mitigation from cognitive and affective aspects. Based on the importance of understanding volcanic disaster mitigation, games are used to measure students' levels of understanding of volcanic disaster mitigation. As well as grouping the results of students playing a volcano disaster mitigation game using the $K$-Means Clustering method consisting of 4 clusters with results less, sufficient, good, and very good criteria value. K-Means Clustering is a method of grouping data with $k$ as a centroid. By taking data from 32 students at SMP Negeri 2 Tanjung Redeb, Berau, East Kalimantan, the students were asked to answer a number of questions related to cognitive and affective aspects three times attempts. Based on the results of students answering questions obtained values - values that will be grouped using K-Means Clustering. From the results of grouping 32 student data, cognitive values given with $x$ coordinate and affective coordinates given with $y$ coordinate were obtained with 4 centroid points in each cluster. Obtained the results of research conducted using the K-Means Clustering method that in the first cluster with fewer criteria value there are 4 students, the second cluster with enough criteria value there are 14 students, the third cluster with good criteria value there are 6 students, and the fourth cluster with very good criteria value there are 8 students. The assessment parameters for students were obtained from the 2013 curriculum guide by teachers of SMP Negeri 2 Tanjung Redeb, Berau, East Kalimantan.
\end{abstract}

Keywords : Affective, Clustering, Cognitive, K-Means, Volcanic Disaster Mitigation.

Manuscript received December 06, 2019. This work was supported in part by Informatics Engineering Department of Maulana Malik Ibrahim Islamic State University.

Muhammad Firyal Alfarisi is with the Informatic Engineering Departement of Maulana Malik Ibrahim Islamic State University, Malang, Indonesia (email Faris@eramulti.com)

Fresy Nugroho., is with the Informatic Engineering Departement of Maulana Malik Ibrahim Islamic State University, Malang, Indonesia.

Muhammad Faisal is is the Informatic Engineering Departement of Maulana Malik Ibrahim Islamic State University, Malang, Indonesia
Abstrak-Bencana alam banyak sekali terjadi di Indonesia, salah satu bencana alam yang terjadi di Indonesia adalah bencana gunung api. Dalam menghadapi bencana gunung api tersebut, para siswa sangat memerlukan pengetahuan tentang mitigasi bencana gunung api dari aspek kognitif dan afektif. Berdasarakan pentingnya pemahaman tentang mitigasi bencana gunung api, digunakanlah game dalam mengukur tingkat pemahaman siswa terhadap mitigasi bencana gunung api. Serta dilakukan pengelompokkan hasil dari siswa memainkan game mitigasi bencana gunung api menggunakan metode K-Means Clustering yang terdiri dari 4 cluster dengan keterangan kurang, cukup, baik, dan sangat baik. K-Means Clustering merupakan suatu metode pengelompokkan data dengan $k$ sebagai centroid. Dengan mengambil data sebanyak 32 siswa pada SMP Negeri 2 Tanjung Redeb, Berau, Kalimantan Timur siswa diminta untuk menjawab beberapa soal terkait aspek kognitif dan afektif sebanyak 3 kali percobaan. Berdasarkan hasil dari siswa menjawab soal didapatkan nilai - nilai yang akan dikelompokkan menggunakan K-Means Clustering. Dari hasil pengelompokkan terhadap 32 data siswa, didapatkan nilai kognitif (koordinat $x$ ) dan afektif (koordinat $y$ ) dengan 4 titik centroid pada tiap masing - masing cluster. Didapatkan hasil penelitian yang dilakukan dengan menggunakan metode K-Means Clustering bahwa pada kluster pertama dengan keterangan kurang terdapat 4 siswa, kluster kedua dengan keterangan cukup terdapat 14 siswa, kluster ketiga dengan keterangan baik terdapat 6 siswa, dan kluster keempat dengan keterangan sangat baik terdapat 8 siswa. Parameter penilaian terhadap siswa didapatkan dari panduan kurikulum 2013 oleh guru guru SMP Negeri 2 Tanjung Redeb, Berau, Kalimantan Timur.

Kata Kunci-Afektif, Clustering, K-Means, Kognitif, Mitigasi Bencana Gunung Api

\section{PENDAhUluan}

B encana alam merupakan suatu hal yang mengancam dan mengganggu kehidupan, bencana alam banyak sekali terjadi di Indonesia, adapun salah satu bencana alam yang terjadi di Indonesia adalah gunung meletus. Gunung meletus merupakan proses alam yang disebabkan oleh aktivitas gunung api yang meliputi asal usul pembentukan magma di dalam bumi hingga kemunculan magma tersebut di permukaan bumi dalam berbagai bentuk dan kegiatannya [1]. Dalam menghadapi bencana gunung api tersebut, perlu adanya pengetahuan mitigasi bencana gunung api serta 
penanggulangannya secara khusus menuntut siswa untuk memahaminya baik secara kognitif dan afektif.

Dengan mengambil tolak ukur siswa SMP dalam penelitian ini tentunya melihat perkembangan kognitif dari siswa SMP dengan rentan umur 11 tahun dan seterusnya, yang telah masuk pada tahap operasional formal, dimana pada tahap ini siswa telah mampu berpikir abstrak, yaitu berpikir tentang ide dan memikirkan beberapa pemecahan masalah tidak lagi menerima informasi apa adanya, tetapi siswa SMP akan memproses informasi itu dan juga mengadaptasikannya dengan pemikiran mereka sendiri [2]. Berdasarkan hal tersebut, pemahaman tentang mitigasi untuk siswa SMP sangatlah penting ditinjau berdasarkan tingkat pemahaman siswa direntan umur 11 tahun dan seterusnya dapat memproses ilmu lebih cepat dan sikap siaga dalam menghadapi bencana.

Pada permasalahan yang diuraikan, ditawarkan sebuah solusi untuk penanganan pengetahuan terhadap mitigasi bencana erupsi gunung api berupa metode $K$ Means Clustering yang akan mengukur tingkat pemahaman siswa berdasarkan dari aspek kognitif dan afektif. Klasterisasi atau yang biasa dikenal dengan clustering adalah suatu metode dalam melakukan pengelompokan data. Proses clustering adalah proses pengelompokkan beberapa data dalam setiap cluster atau kelompok yang telah ditentukanm, dan setiap cluster yang telah ditentukan memiliki kemiripan dan karakteristik yang sama.

\section{PENELITIAN TERKAIT}

Penelitian sejenis yang pernah dilakukan yaitu pada penelitian yang membahas pembelajaran K-Means Clustering dengan menggunakan taksonomi Bloom Serious Game (BoTySeGa) yang dibuat oleh I Nyoman Sukajaya pada tahun 2015. Inti dari penelitian ini adalah membahas permainan yang terintegrasi dengan pembelajaran domain kognitif taksonomi Bloom [3]. Penelitian sejenis yang lain yaitu untuk meningkatkan hasil belajar siswa dari aspek kognitif dan psikomotorik dalam membuat sketsa dan peta wilayah yang menggambarkan objek geografi terhadap siswa kelas VII. Penelitian ini mengukur bahwa dengan penerapan metode survei lapangan dapat meningkatkan hasil belajar siswa ditinjau dari aspek kognitif dan psikomotorik [4]. Penelitian sejenis yang lain dimana peneliti menggali kemampuan mahasiswa khususnya strata satu untuk mengetahui tingkat kemampuan mahasiswa dalam aspek kognitif berdasarkan pemanfaatan teknologi informasi dengan melakukan klasterisasi atau pengelompokan berdasarkan pengetahuan dari masing - masing mahasiswa. Hasil dari penelitian ini adalah mengetahui sebatas tingkat pemahaman mahasiswa berdasarkan tingkat kemampuan dari aspek kognitif terhadap suatu teknologi informasi dikelompokkan dengan $K$-Means [5].

\section{ALUR PENGUMPULAN DATA}

\section{A. Blok Diagram Penelitian}

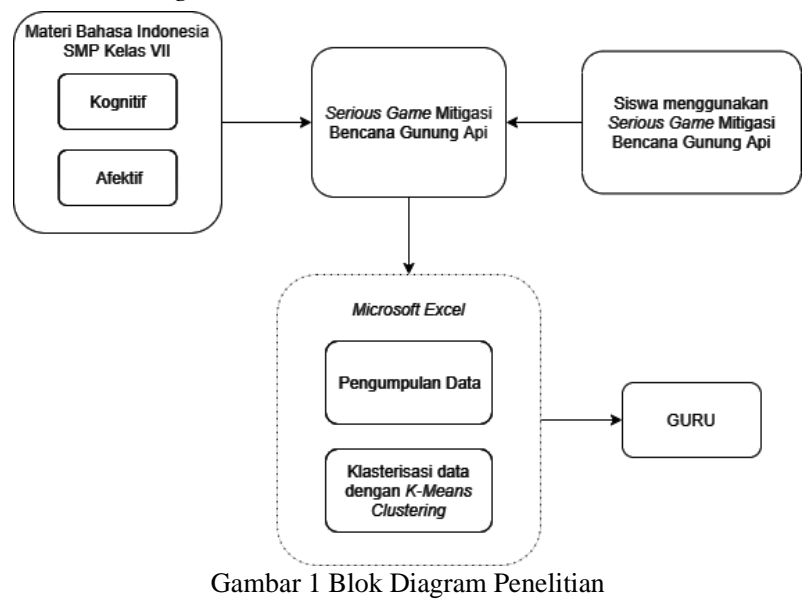

Berdasarkan Gambar 1 siswa memainkan game mitigasi bencana gunung api dengan aspek kognitif dan afektif. Siswa diminta untuk menjawab soal sebanyak 10 aspek kognitif dan 10 aspek afektif tentang mitigasi bencana gunung api yang telah disediakan didalam game. Data yang telah diperoleh dan dikumpulkan ke dalam Microsoft Excel guna dilakukan pengelompokkan terhadap data - data yang diperoleh dengan menggunakan metode $K$-Means Clustering.

\section{B. K-Means Clustering}

Dalam melakukan clustering tentunya dibutuhkanlah suatu data yang dapat dikelompokkan menjadi beberapa cluster dengan menggunakan metode K-Means. Adapun algoritma dalam menghitung $K$-Means Clustering yang akan digunakan dengan data yang diperoleh yaitu :

1. Menentukan jumlah cluster

2. Menentukan nilai awal dari centroid

3. Menghitung jarak antara centroid dengan data

4. Menentukan atau memperbarui centroid

5. Menghitung kembali jarak centroid dengan data

6. Lakukan lah pengulangan pada proses ke-4 dan ke-5 sampai menghasilkan cluster yang sama.

Dalam penelitian ini diambil suatu contoh data nilai mata pelajaran Bahasa Indonesia kelas VII (tujuh) siswa SMP Negeri 2 Tanjung Redeb, Kabupaten Berau, Kalimantan Timur. Berdasarkan 2 aspek pengambilan data dari hasil kerja siswa yaitu aspek kognitif dan afektif dengan setiap bobot soal pada Tabel 1 .

\begin{tabular}{cc} 
Tabel 1 Bobot Soal & \\
\hline Nomor soal & Bobot \\
\hline 1 & 10 \\
2 & 10 \\
3 & 10 \\
4 & 10 \\
5 & 10 \\
6 & 10 \\
7 & 10 \\
8 & 10 \\
9 & 10 \\
10 & 10 \\
\hline Jumlah & 100 \\
\hline
\end{tabular}




\section{Proses Perhitungan K-Means Clustering}

Dalam melakukan perhitungan $K$-Means Clustering tentunya membutuhkan data yang akan dikelompokkan menjadi beberapa cluster.

\section{A. Sumber Data}

Penelitian dilakukan dengan mengambil data nilai siswa kelas VII (tujuh) E SMP Negeri 2 Tanjung Redeb, Kabupaten Berau, Kalimantan Timur. Dalam penelitian yang dilakukan, siswa diminta untuk memainkan game dan menjawab beberapa pertanyaan terkait mitigasi bencana gunung api sehingga dapat dinilai aspek kognitif dan aspek afektif pada game yang telah dibangun. Pada Tabel 2 adalah 32 daftar nama siswa yang diperoleh.

Tabel 2 Data 32 Siswa SMP Negeri 2 Tanjung Redeb, Berau, Kalimantan Timur.

\begin{tabular}{lc}
\hline \multicolumn{1}{c}{ Nama } & Jenis \\
& Kelamin \\
\hline Adenia & $\mathrm{P}$ \\
Adira Nazma Prasasti & $\mathrm{P}$ \\
Andika Reza Soneri & $\mathrm{L}$ \\
Annata Nur Shafa & $\mathrm{P}$ \\
Chandra Jecy Linde & $\mathrm{L}$ \\
Cheverlly Dhista Putri Joseffine & $\mathrm{P}$ \\
Daffa Nail Mubarak & $\mathrm{L}$ \\
Dennis Alfito Wahyu Pratama & $\mathrm{L}$ \\
Derly Izza Abdillah Junaidi & $\mathrm{L}$ \\
Gea Laura Apriliya Amanda & $\mathrm{P}$ \\
Gilbeth Stiven & $\mathrm{L}$ \\
Khairani Tosuli & $\mathrm{P}$ \\
Kholil Naraya Adam & $\mathrm{L}$ \\
Luna Meilani Putri Hutagalung & $\mathrm{P}$ \\
Muhammad Daffa Syaifullah & $\mathrm{L}$ \\
Muhammad Syahril & $\mathrm{L}$ \\
Muhammad Alif Alfarizi & $\mathrm{L}$ \\
Muhammad Arya Maulana & $\mathrm{L}$ \\
Muhammad Dhany Fajar Susilo & $\mathrm{L}$ \\
Muhammad Nur Salam & $\mathrm{L}$ \\
Muhammad Rehan & $\mathrm{L}$ \\
Muhammad Shifa Caisar Rizki & $\mathrm{L}$ \\
Muhammad Zakhi Prayogi & $\mathrm{L}$ \\
Nadya Oktavia Ramadhani & $\mathrm{P}$ \\
Niswa Juhaida Florita & $\mathrm{P}$ \\
Novi Qomariah Wati & $\mathrm{P}$ \\
Shelia Dwi Febrianti & $\mathrm{P}$ \\
Siti Aisah & $\mathrm{P}$ \\
Styven Anthony & $\mathrm{L}$ \\
Suci Lia Ramadhani & $\mathrm{P}$ \\
Ulfah Alfiyah Handayani & $\mathrm{P}$ \\
Ulfi Ramadhani & $\mathrm{P}$ \\
\hline & \\
\hline &
\end{tabular}

\section{B. Prosedur Penelitian}

Penelitian dilakukan dengan 32 siswa SMP Negeri 2 Tanjung Redeb, Berau, Kalimantan Timur menjawab pertanyaan yang disediakan pada game seputar aspek kognitif dan afektif dengan masing - masing soal tiap aspek adalah 10 butir soal. Tampilan layout dari pertanyaan di game dari aspek kognitif dan afektif sebagai berikut.

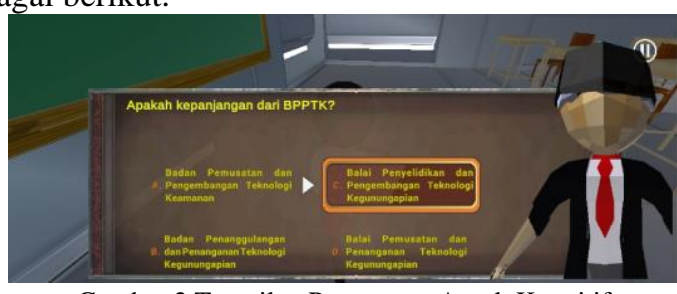

Gambar 2 Tampilan Pertanyaan Aspek Kognitif

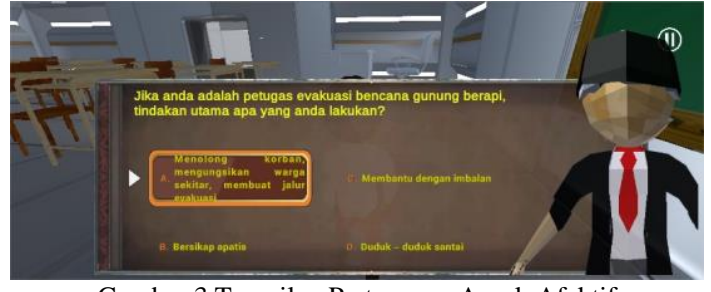

Gambar 3 Tampilan Pertanyaan Aspek Afektif

\section{C.Alur Perhitungan Data Menggunakan K-Means} Clustering

Data yang diperoleh sebanyak 32 data siswa dihitung dengan menentukan jumlah kluster dan menentukan titik centroid yang kemudian mengukur jarak data dengan titik centroid menggunakan persamaan Euclidean Distance [6].

$$
D_{L_{2}}\left(x_{2}, x_{1}\right)=\left\|x_{2}-x_{1}\right\|_{2}=\sqrt{\sum_{j=1}^{p}\left(x_{2_{j}}-x_{1_{j}}\right)^{2}}
$$

Dimana DL2 merupakan jarak kuadrat Euclidean antar objek x2 dengan x1, p adalah jumlah variabel cluster, $\mathrm{x} 2 \mathrm{j}$ nilai atau data dari objek ke-2 pada variabel ke-j, $\mathrm{x} 1 \mathrm{j}$ nilai atau data dari objek ke-1 pada variabel ke-j.

\section{Uji Validasi}

Validasi yang dilakukan dari hasil pengujian untuk memastikan ketepatan hasil dari clustering. Dengan membandingkan jarak menggunakan persamaan Euclidean Distance untuk menghitung antara data dengan setiap rata - rata nilai akhir titik centroid. Dengan data yang diperoleh adalah 32 data nilai siswa yang telah menjawab soal yang diberikan terkait aspek kognitif dan afektif terhadap mitigasi bencana gunung api.

Tabel 3 Hasil Validasi

\begin{tabular}{|c|c|c|c|c|c|c|}
\hline Nama & $\begin{array}{ll}\mathrm{C} & - \\
1 & \\
\end{array}$ & $\begin{array}{ll}\mathrm{C} & - \\
2 & \\
\end{array}$ & $\begin{array}{ll}\mathrm{C} & - \\
3 & \end{array}$ & $\begin{array}{ll}\mathrm{C} & - \\
4 & \end{array}$ & Cluster & $\begin{array}{l}\text { Kecocoka } \\
\text { n Sistem }\end{array}$ \\
\hline Adenia & $\begin{array}{c}33,9 \\
2\end{array}$ & 13,59 & 1,58 & 16,68 & Baik & VALID \\
\hline $\begin{array}{l}\text { Adira } \\
\text { Nazma } \\
\text { Prasasti }\end{array}$ & $\begin{array}{c}40,0 \\
1\end{array}$ & 18,70 & 17,40 & 2,94 & $\begin{array}{c}\text { Sangat } \\
\text { Baik }\end{array}$ & VALID \\
\hline $\begin{array}{l}\text { Andika } \\
\text { Reza } \\
\text { Soneri }\end{array}$ & $\begin{array}{c}35,6 \\
1\end{array}$ & 17,11 & 4,96 & 20,82 & Baik & VALID \\
\hline $\begin{array}{l}\text { Annata Nur } \\
\text { Shafa }\end{array}$ & $\begin{array}{c}40,2 \\
2\end{array}$ & 18,45 & 5,99 & 11,92 & Baik & VALID \\
\hline $\begin{array}{l}\text { Chandra } \\
\text { Jecy Linde } \\
\text { Cheverlly }\end{array}$ & $\begin{array}{c}27,7 \\
0\end{array}$ & 5,39 & 11,34 & 14,35 & Cukup & VALID \\
\hline $\begin{array}{l}\text { Dhista } \\
\text { Putri } \\
\text { Joseffine }\end{array}$ & $\begin{array}{c}17,6 \\
6\end{array}$ & 9,29 & 18,23 & 27,94 & Cukup & VALID \\
\hline $\begin{array}{l}\text { Daffa Nail } \\
\text { Mubarak } \\
\text { Dennis }\end{array}$ & $\begin{array}{c}28,0 \\
0\end{array}$ & 7,38 & 15,48 & 13,55 & Cukup & VALID \\
\hline $\begin{array}{l}\text { Alfito } \\
\text { Wahyu } \\
\text { Pratama }\end{array}$ & 3,44 & 20,64 & 32,98 & 40,11 & $\begin{array}{c}\text { Kuran } \\
\mathrm{g}\end{array}$ & VALID \\
\hline $\begin{array}{l}\text { Derly Izza } \\
\text { Abdillah } \\
\text { Junaidi }\end{array}$ & $\begin{array}{c}21,6 \\
1\end{array}$ & 7,59 & 21,24 & 20,76 & Cukup & VALID \\
\hline
\end{tabular}




\begin{tabular}{|c|c|c|c|c|c|c|}
\hline $\begin{array}{l}\text { Gea Laura } \\
\text { Apriliya } \\
\text { Amanda }\end{array}$ & $\begin{array}{c}31,0 \\
1\end{array}$ & 10,26 & 4,59 & 16,26 & Baik & VALID \\
\hline $\begin{array}{l}\text { Gilbeth } \\
\text { Stiven }\end{array}$ & $\begin{array}{c}20,8 \\
3\end{array}$ & 9,95 & 15,72 & 26,98 & Cukup & VALID \\
\hline $\begin{array}{l}\text { Khairani } \\
\text { Tosuli }\end{array}$ & 4,16 & 23,45 & 37,35 & 41,83 & $\begin{array}{c}\text { Kuran } \\
\mathrm{g}\end{array}$ & VALID \\
\hline $\begin{array}{l}\text { Kholil } \\
\text { Naraya } \\
\text { Adam } \\
\text { Luna }\end{array}$ & 2,50 & 20,72 & 34,31 & 39,55 & $\begin{array}{c}\text { Kuran } \\
\mathrm{g}\end{array}$ & VALID \\
\hline $\begin{array}{l}\text { Meilani } \\
\text { Putri } \\
\text { Hutagalung }\end{array}$ & $\begin{array}{c}22,0 \\
0\end{array}$ & 6,95 & 13,57 & 23,76 & Cukup & VALID \\
\hline $\begin{array}{l}\text { Muhamma } \\
\text { d Daffa } \\
\text { Syaifullah }\end{array}$ & $\begin{array}{c}48,9 \\
4\end{array}$ & 26,74 & 19,02 & 8,02 & $\begin{array}{l}\text { Sangat } \\
\text { Baik }\end{array}$ & VALID \\
\hline $\begin{array}{l}\text { Muhamma } \\
\text { d Syahril }\end{array}$ & $\begin{array}{c}28,0 \\
0\end{array}$ & 7,38 & 15,48 & 13,55 & Cukup & VALID \\
\hline $\begin{array}{l}\text { Muhamma } \\
\text { d Alif } \\
\text { Alfarizi }\end{array}$ & $\begin{array}{c}33,9 \\
2\end{array}$ & 13,59 & 1,58 & 16,68 & Baik & VALID \\
\hline $\begin{array}{l}\text { Muhamma } \\
\text { d Arya } \\
\text { Maulana }\end{array}$ & $\begin{array}{c}37,3 \\
5\end{array}$ & 15,65 & 14,49 & 4,12 & $\begin{array}{c}\text { Sangat } \\
\text { Baik }\end{array}$ & VALID \\
\hline $\begin{array}{l}\text { Muhamma } \\
\text { d Dhany } \\
\text { Fajar } \\
\text { Susilo }\end{array}$ & $\begin{array}{c}37,1 \\
3\end{array}$ & 14,82 & 9,94 & 6,26 & $\begin{array}{c}\text { Sangat } \\
\text { Baik }\end{array}$ & VALID \\
\hline $\begin{array}{l}\text { Muhammad } \\
\text { Nur Salam }\end{array}$ & $\begin{array}{c}20,8 \\
4\end{array}$ & 2,63 & 15,12 & 21,80 & Cukup & VALID \\
\hline $\begin{array}{l}\text { Muhamma } \\
\text { d Rehan }\end{array}$ & $\begin{array}{c}29,1 \\
6\end{array}$ & 21,61 & 33,43 & 26,41 & Cukup & VALID \\
\hline $\begin{array}{l}\text { Muhamma } \\
\text { d Shifa } \\
\text { Caisar } \\
\text { Rizki }\end{array}$ & $\begin{array}{c}23,4 \\
7\end{array}$ & 14,39 & 16,40 & 29,72 & Cukup & VALID \\
\hline $\begin{array}{l}\text { Muhamma } \\
\text { d Zakhi } \\
\text { Prayogi }\end{array}$ & $\begin{array}{c}26,1 \\
6\end{array}$ & 8,00 & 18,63 & 16,08 & Cukup & VALID \\
\hline $\begin{array}{l}\text { Nadya } \\
\text { Oktavia } \\
\text { Ramadhani }\end{array}$ & $\begin{array}{c}20,8 \\
3\end{array}$ & 9,95 & 15,72 & 26,98 & Cukup & VALID \\
\hline $\begin{array}{l}\text { Niswa } \\
\text { Juhaida }\end{array}$ & $\begin{array}{c}22,9 \\
9\end{array}$ & 0,75 & 14,49 & 18,86 & Cukup & VALID \\
\hline $\begin{array}{l}\text { Florita } \\
\text { Novi }\end{array}$ & & & & & & \\
\hline $\begin{array}{l}\text { Qomariah } \\
\text { Wati }\end{array}$ & $\begin{array}{c}45,5 \\
9\end{array}$ & 25,01 & 23,54 & 7,65 & $\begin{array}{l}\text { Sangat } \\
\text { Baik }\end{array}$ & VALID \\
\hline $\begin{array}{l}\text { Shelia Dwi } \\
\text { Febrianti }\end{array}$ & $\begin{array}{c}38,4 \\
5\end{array}$ & 17,39 & 3,14 & 14,74 & Baik & VALID \\
\hline Siti Aisah & $\begin{array}{c}44,2 \\
3\end{array}$ & 22,05 & 15,60 & 3,77 & $\begin{array}{l}\text { Sangat } \\
\text { Baik }\end{array}$ & VALID \\
\hline $\begin{array}{l}\text { Styven } \\
\text { Anthony }\end{array}$ & 4,17 & 25,34 & 37,60 & 44,76 & $\begin{array}{c}\text { Kuran } \\
\mathrm{g}\end{array}$ & VALID \\
\hline $\begin{array}{l}\text { Suci Lia } \\
\text { Ramadhani }\end{array}$ & $\begin{array}{c}27,7 \\
0\end{array}$ & 5,39 & 11,34 & 14,35 & Cukup & VALID \\
\hline $\begin{array}{l}\text { Ulfah } \\
\text { Alfiyah } \\
\text { Handayani }\end{array}$ & $\begin{array}{c}35,3 \\
6\end{array}$ & 14,49 & 16,52 & 6,90 & $\begin{array}{c}\text { Sangat } \\
\text { Baik }\end{array}$ & VALID \\
\hline $\begin{array}{l}\text { Ulfi } \\
\text { Ramadhani }\end{array}$ & $\begin{array}{c}44,2 \\
3\end{array}$ & 22,05 & 15,60 & 3,77 & $\begin{array}{l}\text { Sangat } \\
\text { Baik }\end{array}$ & VALID \\
\hline
\end{tabular}

Berdasarkan Tabel 3 didapatkan hasil validasi dengan mengukur jarak kedekatan antara data dengan titik centroid. Berdasarkan hasil tersebut, $\mathrm{C}-1, \mathrm{C}-2, \mathrm{C}-3$, $\mathrm{C}-4$ merupakan suatu cluster dan juga titik dari centroid yang telah dihitung dengan membandingkan jarak dari tiap cluster. Dari hasil yang diperoleh, semakin kecil angka dari hasil penelitian yang dilakukan, maka semakin mendekati jarak dengan titik centroid yang telah ditentukan. Sebagai contoh, pada Tabel 3 data siswa pertama yang bernama Adenia memiliki nilai jarak yang berbeda - beda pada tiap titik centroid $\mathrm{C}-1, \mathrm{C}-2, \mathrm{C}-3, \mathrm{C}-4$. Dari hasil perhitungan tersebut, dapat disimpulkan bahwa nilai terkecil yang dihasilkan menunjukkan pada centroid 3 atau $\mathrm{C}-3$, yang berarti siswa bernama Adenia dikelompokkan kedalam cluster 3 dengan keterangan baik. Dari percobaan terhadap 32 data siswa, menunjukkan hasil untuk keseluruhan data adalah sesuai dengan hasil dari perhitungan sistem. Penilaian keterangan pada Tabel 3 didasarkan kepada keputusan penilaian oleh guru - guru SMP Negeri 2 Tanjung Redeb, Berau, Kalimantan Timur, dan yang berlaku sebagai penanggung jawab adalah ibu Retno Kustiyah, M.Pd. Menurut guru - guru SMP Negeri 2 Tanjung Redeb, Berau, Kalimantan Timur, indikator penilaian tersebut didasarkan kepada panduan kurikulum 2013. Sehingga, indikator penilaian tersebut disesuaikan kepada sistem pada penelitian ini yaitu K-Means Clustering.

\section{HASIL UJI COBA DAN ANALISA}

Berdasarkan perhitungan dari 32 data siswa yang diperoleh menggunakan K-Means Clustering dengan cluster atau centroid yang ditentukan berjumlah 4 maka hasil yang didapat di tiap titik - titik centroid memiliki nilai yang berbeda. Berikut adalah nilai dari tiap titik centroid yang diperoleh.
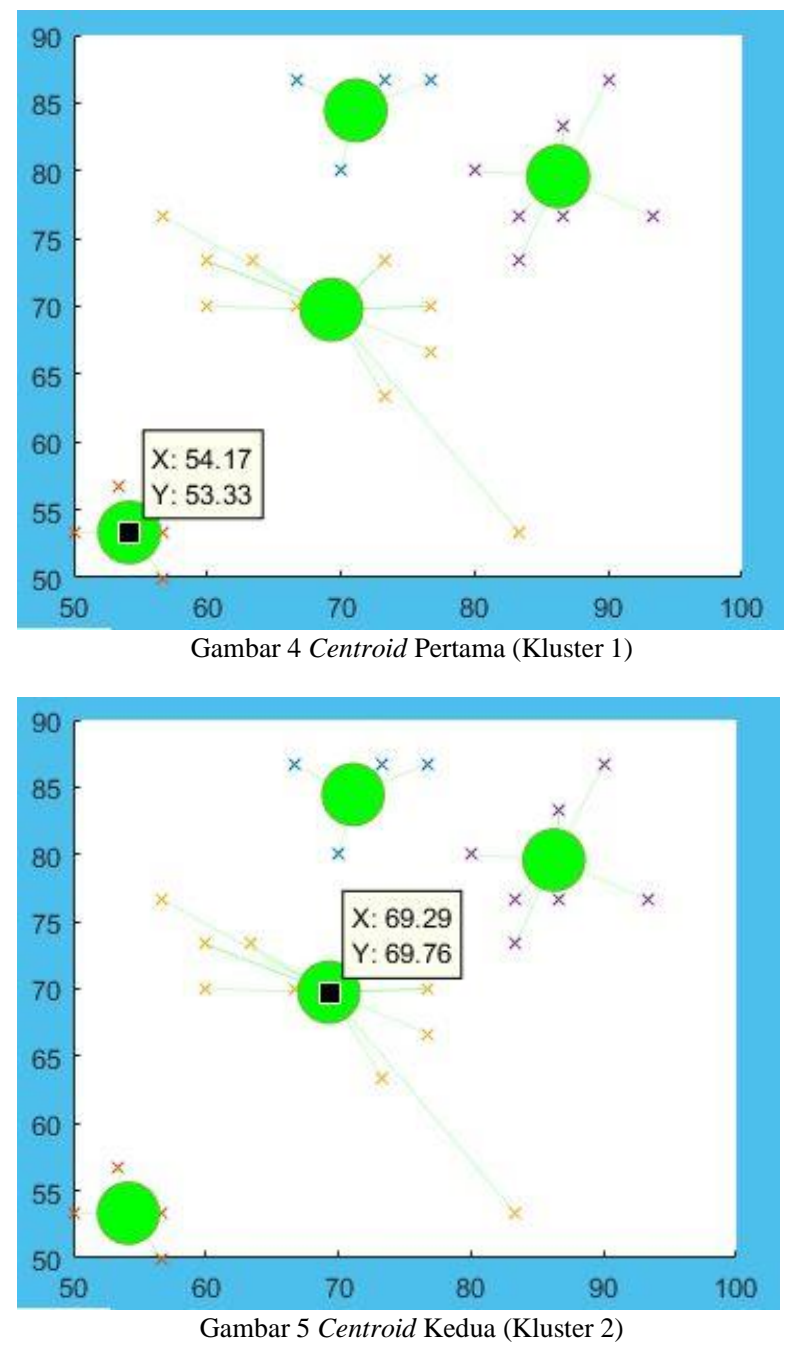


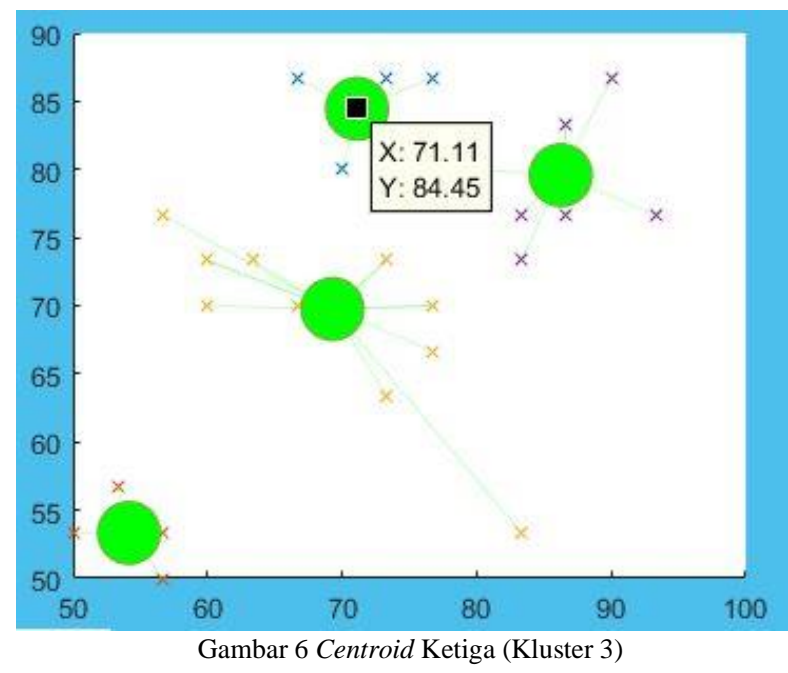

Amanda

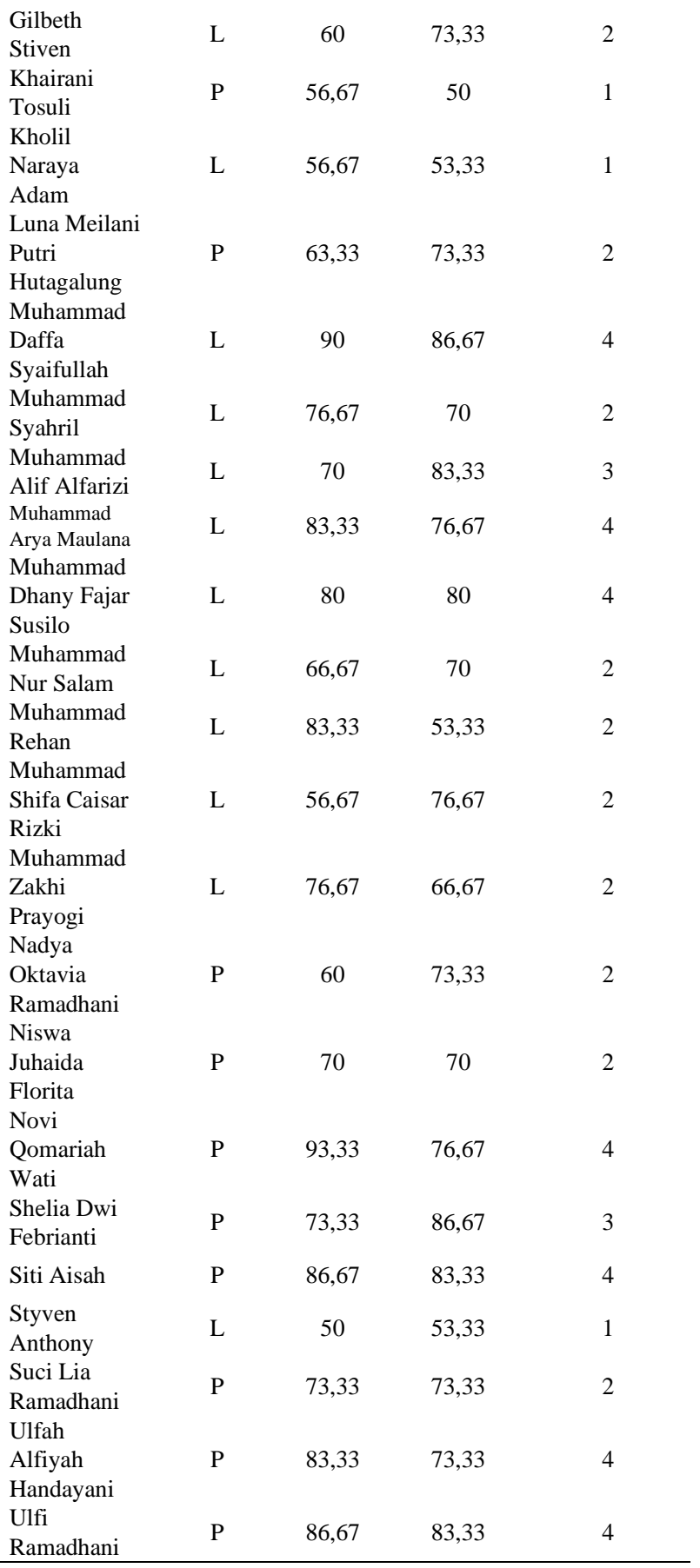

Dari titik centroid yang dihasilkan, tentunya terdapat beberapa data yang memiliki karakteristik yang sama terhadap satu di tiap titik centroid. Berdasarkan titik titik centroid tersebut berikut data - data yang berada pada tiap centroid.

Tabel 4 Hasil Perhitungan K-Means Clustering

\begin{tabular}{lcccc}
\hline Nama & $\begin{array}{c}\text { Jenis } \\
\text { Kelamin }\end{array}$ & $\begin{array}{c}\text { Nilai } \\
\text { Kognitif }\end{array}$ & $\begin{array}{c}\text { Nilai } \\
\text { Afektif }\end{array}$ & Cluster \\
\hline Adenia & $\mathrm{P}$ & 70 & 83,33 & 3 \\
$\begin{array}{l}\text { Adira Nazma } \\
\text { Prasasti }\end{array}$ & $\mathrm{P}$ & 86,67 & 76,67 & 4 \\
$\begin{array}{l}\text { Andika Reza } \\
\text { Soneri } \\
\text { Annata Nur }\end{array}$ & $\mathrm{L}$ & 66,67 & 86,67 & 3 \\
$\begin{array}{l}\text { Shafa } \\
\text { Chandra Jecy }\end{array}$ & $\mathrm{P}$ & 76,67 & 86,67 & 3 \\
$\begin{array}{l}\text { Linde } \\
\text { Cheverlly }\end{array}$ & $\mathrm{L}$ & 73,33 & 73,33 & 2 \\
$\begin{array}{l}\text { Dhista Putri } \\
\text { Joseffine }\end{array}$ & $\mathrm{P}$ & 60 & 70 & 2 \\
$\begin{array}{l}\text { Daffa Nail } \\
\text { Mubarak }\end{array}$ & $\mathrm{L}$ & 76,67 & 70 & 2 \\
$\begin{array}{l}\text { Dennis Alfito } \\
\text { Wahyu }\end{array}$ & $\mathrm{L}$ & 53,33 & 56,67 & 2 \\
$\begin{array}{l}\text { Pratama } \\
\text { Derly Izza } \\
\text { Abdillah }\end{array}$ & $\mathrm{L}$ & 73,33 & 63,33 & 2 \\
$\begin{array}{l}\text { Junaidi } \\
\text { Gea Laura } \\
\text { Apriliya }\end{array}$ & $\mathrm{P}$ & 70 & 80 & 2 \\
& & & & \\
\hline
\end{tabular}

Berdasarkan Tabel 4 dari 32 data nilai siswa yang berbeda, dikelompokkan terhadap 4 cluster yang mana pada masing - masing data memiliki cluster sesuai nilai yang telah dihitung berdasarkan jarak centroid. Berikut adalah banyaknya data dari tiap cluster dari keseluruhan data. 


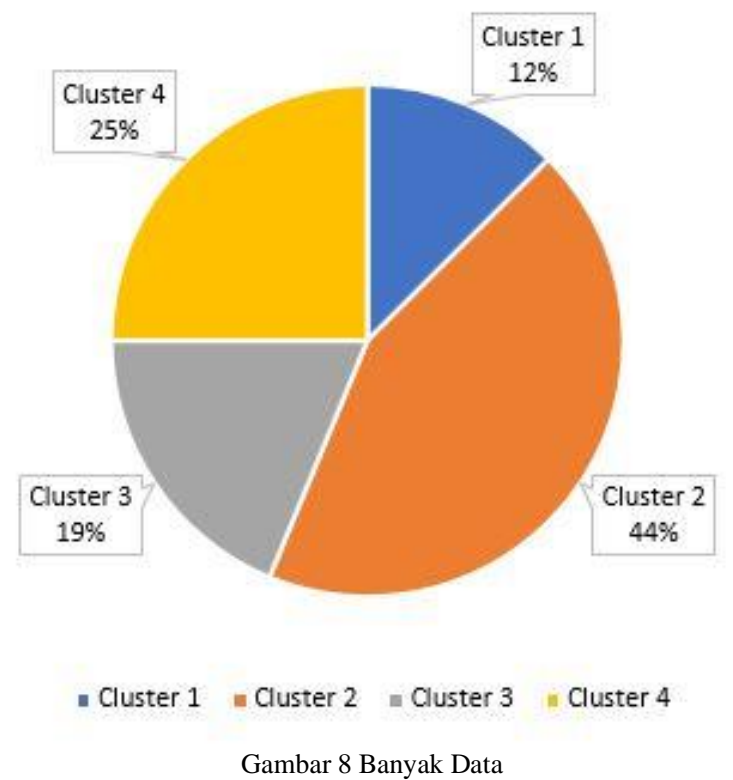

Pada Gambar 8 merupakan hasil dari 32 data nilai siswa yang memiliki persentase berbeda - beda pada tiap cluster. Dari keseluruhan siswa, $12 \%$ masuk pada cluster pertama dengan jumlah data adalah 4, $44 \%$ masuk pada cluster kedua dengan jumlah data adalah 14, $19 \%$ masuk pada cluster ketiga dengan jumlah data adalah 6 , dan $25 \%$ masuk pada cluster keempat dengan jumlah data adalah 8. Berikut keterangan dari keempat kluster berdasarkan pengelompokkan data - data.

Tabel 5 Keterangan Cluster

\begin{tabular}{lcc}
\multicolumn{1}{c}{ Kluster } & $\begin{array}{c}\text { Persentase } \\
\text { Keseluruhan } \\
\text { Data }\end{array}$ & Keterangan \\
& $12 \%$ & Kurang \\
Kluster Pertama & $44 \%$ & Cukup \\
Kluster Kedua & $19 \%$ & Baik \\
Kluster Ketiga & $25 \%$ & Sangat Baik \\
Kluster Keempat & & \\
\hline
\end{tabular}

\section{KESIMPULAN}

Berdasarkan pada game pembelajaran mitigasi bencana gunung api dalam penerapan metode $K$-Means Clustering yang telah dibangun dan diuji coba, didapatkan kesimpulan dimana peneliti berhasil menerapkan metode K-Means Clustering pada game mitigasi bencana gunung api dengan mengambil aspek kognitif dan afektif pada siswa kelas VII (tujuh) SMP Negeri 2 Tanjung Redeb, Berau, Kalimantan Timur. Penelitian ini dilakukan untuk menguji sistem $K$-Means Clustering yang digunakan untuk mengukur serta mengetahui pemahaman siswa terhadap mitigasi bencana gunung api dari aspek kognitif serta afektif. Penelitian dilakukan dengan mengambil data nilai siswa kelas VII (tujuh) E SMP Negeri 2 Tanjung Redeb, Kabupaten Berau, Kalimantan Timur. Dari hasil penelitian yang dilakukan, siswa diminta untuk memainkan game dan menjawab beberapa pertanyaan terkait mitigasi bencana gunung api sehingga dapat dinilai aspek kognitif dan afektif pada game yang telah dibangun. Didapatkan data sebanyak 32 siswa pada kelas VII (tujuh) E SMP Negeri 2 Tanjung Redeb, Kabupaten Berau, Kalimantan Timur, dengan dilakukan 3 kali percobaan. Berdasarkan pengujian 32 data tersebut, didapatkan hasil pada cluster pertama dengan keterangan kurang terdapat 4 data, pada cluster kedua dengan keterangan cukup terdapat 14 data, pada cluster ketiga dengan keterangan baik terdapat 6 data, dan cluster keempat dengan keterangan sangat baik terdapat 8 data.

\section{REFERENSI}

[1] S. Bronto, "Fasies Gunung Api dan Aplikasinya," Indonesian Journal on Geoscience, vol. 2, pp. 59-71, 2006.

[2] \&. H. Suyono, Belajar dan Pembelajaran : Teori dan Konsep Dasar, Bandung: Remaja Rosdakarya, 2014.

[3] I. N. Sukajaya, I. K. E. Purnama and M. H. Purnomo, K-Means Clustering Of Learners' Cognitive Domain Measured Using Bloom's Taxonomy-Based Serious Game, pp. 110-115, 2015.

[4] W. Kristiningtyas, "Peningkatan Hasil Belajar Aspek Kognitif Dan Psikomotorik Dalam Membuat Sketsa Dan Peta Wilayah Yang Menggambarkan Objek Geografi Melalui Metode Survei Lapangan," Jurnal Refleksi Edukatika, 2017.

[5] J. C. Bezdek, Pattern Recognition with Fuzzy Objective Function Algoritmss, 1981.

[6] D. Kriestanto and D. Fakta, "Clustering Aspek Kognitif Mahasiswa Terhadap Pemanfaatan Teknologi Informasi," Jurnal Teknologi Informasi, vol. IX, 2016. 